Volume 10 Issue 1 (2021) Pages 25-34

Ta'dib: Jurnal Pendidikan Islam

ISSN: 2528-5092 (Online) 1411-8173 (Print)

https://ejournal.unisba.ac.id/index.php/tadib/article/view/7481

\title{
HUMAN CONCEP'T OF THE ENVIRONMENT AND THE UNIVERSE PERSPECTIVE OF THE QURAN
}

\author{
Tian Khusni Akbar ${ }^{1}$, Mhd. Lailan Arqam ${ }^{2}$ \\ Program Studi Magister Pendidikan Agama Islam, Universitas Ahmad Dahlan ${ }^{1,2}$ \\ Email: ${ }^{1}$ tian2007052024@webmail.uad.ac.id, ${ }^{2}$ muhammad.arqam@mpai.uad.ac.id. \\ DOI: https://doi.org/10.29313/tjpi.v10i1.7481. \\ Received: January 21th, 2020. Accepted: May 1th, 2021. Published: May 1th, 2021.
}

\begin{abstract}
This article examines the buman concept of the environment and the universe from the point of view of the Qur'an. This study is based on the lack of buman concern for the environment. Several verses in the Al-Qur'an emphasize probibitions and reprisals for those who damage the environment and those who protect it. The research approach is qualitative type of literature. The data sources are literature in the field of environment, Al-Qur'an and Tafseer. Data engineering is carried out with related references, both manually and digitally, especially in the Google Scholar database with the keyword used is the Concept of Humans Against the Environment and the Universe in the Perspective of the Qur'an. The collected data were then analyzed using inductive thinking patterns. The results of the research show that bumans and the environment have a relationship where bumans as caliphs on earth must always think about what has been bestowed by Allah SWT, so that they are able to make real natural resources, and the creation of the natural environment makes humans always remember the main purpose of being created on earth, namely to pronunciation to Allab SWT.
\end{abstract}

Keywords: Human; Environment; Al-Qur'an.

\begin{abstract}
Abstrak
Artikel ini mengulas tentang konsep manusia terhadap lingkungan dan alam semesta dari sudut pandang AlQur'an. Kajian ini di latar belakangi oleb masih minimnya kepedulian manusia terhadap lingkungan. Beberapa ayat di dalam Al-Qur'an menekankan akan larangan, dan balasan bagi orang yang merusak. lingkungan maupun yang menjaganya. Pendekatan penelitian ini adalah kualitatif jenis kepustakaan. Sumber data penelitian ini merupakan literatur di bidang lingkungan, Al-Qur'an dan Tafsir. Teknik, pengumpulan data dilakukan dengan menelusuri referensi terkait, baik secara manual maupun digital, terutama dalam data base google cendekia dengan kata kunci yang digunakan adalah Konsep Manusia Terbadap Lingkungan dan Alam Semesta Perspektif AlQur'an. Data yang terkumpul kemudian dianalisis secara kualitatif dengan menggunakan pola berpikir induktif. Hasil penelitian menunjukan bahwa manusia dan lingkungan memiliki sebuah relasi dimana manusia sebagai khalifah dibumi harus senantiasa berfikir akan apa yang sudah dianugrabkan oleh Allah SWT, sehingga mampu menjadikan alam sumber kehidupan yang nyata, dan diciptakannya alam lingkungan menjadikan manusia senantiasa mengingat akan tujuan utama diciptakan dimuka bumi yaitu untuk beribadah kepada Allah SWT.
\end{abstract}

Kata Kunci: Manusia; Lingkungan; Al-Qur'an. 


\section{PENDAHULUAN}

Menjaga, merawat dan menghijaukan lingkungan merupakan bentuk kewajiban bagi manusia sebagai bentuk wujud ketaatan kepada sang Khaliq. Tujuan manusia diciptikan oleh Allah adalah menyembah, namun selain itu manusia juga diciptakan sebagai khalifatulloh fil ard (Kholifah Allah di bumi). Di kalangan ahli agama kepedulian akan lingkungan baru muncul pada sekitar tahun 1970-an sebagai bentuk akibat dari tumbuhnya kesadaran ekologi pada tahun 1960-an, tepatnya ketika artikel karya Lynn White, Jr. Diterbitkan di majalah "Science" pada tahun 1967. Ini menjelaskan bahwa masalah lingkungan global bermula dari keyakinan agama. Sejak saat itulah, perbincangan masalah ekologi menjadi dominan. (Kaveh L. Afrasiabi, 2003).

Minimnya kesadaran dan kepedulian manusia dalam menjaga Alam, merupakan bukti bahwa manusia pada dekade ini belum bisa mengimplementasikan apa yang sudah Allah wahyukan di dalam Al-Qur'an. Sebagaimana yang diutarakan oleh (Mangunjaya, 2013) terdapat tiga tantangan utama yang dihadapi oleh umat manusia dalam mengatasi krisis lingkungan pada abad 21 yaitu (1) terjadinya peningkatan populasi, (2) degradasi dan hilangnya sumberdaya, dan (3) perubahan iklim. Manusia memiliki tugas untuk memanfaatkan, mengelola dan memelihara alam semesta. Allah menciptakan alam semesta untuk kepentingan dan kesejahteraan semua makhluk-Nya, khususnya manusia. Alam sebagai wujud dari ciptaan Allah mampu memberikan segala hal yang dibutuhkan manusia agar menjadi suatu sumber kehidupan yang positif. Karena pada hakikatnya rusakanya lingkungan adalah bentuk perlakuan buruk manusia terhadap alam, sehingga akan bertimbal balik pada manusia itu sendiri dengan berbagai bencana alam yang ada. Sebagaimana yang Allah Wahyukan pada pada Q.S Ar Rum ayat 41 yang artinya:

"Telah tampak kerusakan di darat dan dilaut disebabkan perbuatan manusia, supaya Allah merasakan kepada mereka sebagian dari (akibat) perbuatan mereka, agar mereka kembali (ke jalan yang benar) (Cahaya Qur'an, 2017).

Dalam Islam, masalah lingkungan hidup mulai dijabarkan dalam Al-Qur'an dengan beragam macam pemaknaan. Diantaranya adalah al-bi'ah (menempati wilayah, ruang kehidupan dan lingkungan) artinya yaitu bahwa lingkungan sebagai ruang kehidupan khususnya bagi manusia (Abdillah, 2001). Maknanya adalah bahwa agama tidak hanya berfokus pada hal ubudiyah semata akan tetapi tetap memperhatikan pada ranah ekologi, khususnya dalam menjaga lingkungan. Sebagaimana yang dijelaskan oleh (La Fua, 2014) bahwa nilai-nilai yang terkandung pada Al-Qur'an \& Hadist bisa dijadikan menjadi landasan berpikir \& bertindak bagi umat muslim dalam menyikapi kerusakan lingkungan, kekayaan nilai yg terkandung pada ayat-ayat Al-Qur'an dan Hadist Nabi 
Muhammad SAW dapat menjadi pendorong bagi umat Islam dalam melastarikan alam \& lingkungan karena merupakan bagian dari perintah dari Allah SWT.

Adanya artikel ini diharapkan mampu menjawab permasalahan yang kompleks tentang konsep penciptaan manusia dalam menjaga lingkungan perspektif Al-Qur'an, dan diharapkan mampu memberikan solusi, pencerahan dan pandangan melalui karya tulis ilmiah, kepada seluruh pembaca sehingga mampu diimplementasikan dalam berbagai riset/study yang selama ini masih belum bisa dioptimalkan atau bahkan dihiraukan begitu saja khususnya tentang keterlibatan AlQur'an yang belum mampu diimplementasikan pada diri manusia dalam menjaga lingkungan.

\section{METODE PENELITIAN}

Adapun jenis artikel ini merupakan penelitian kualitatif yang didasarkan pada kajian kepustakaan yaitu serangkaian penelitian yang berkenaan dengan cara pengumpulan data kepustakaan (jurnal ilmiah, dokumen, buku, artikel dll (Sukmadinata, 2009). Adapun sifat dari penelitian ini merupakan deskriptif analisis yaitu penguraian secara teratur seluruh konsep kemudian pemberian pemahaman dan penjelasan dari hasil yang menjadi objek deskripsi. Teknik pengumpulan data dilakukan dengan menelusuri referensi terkait, baik secara manual maupun digital, terutama dalam data base google cendekia dengan kata kunci yang digunakan adalah konsep manusia, lingkungan hidup, Ayat-ayat tentang lingkungan hidup. Setelah data terkumpul, langkah selanjutnya adalah melakukan penelaahan yang hubungannya dengan masalah yang diteliti, sehingga memperoleh data dan bahan untuk penelitian. Data yang terkumpul kemudian dianalisis secara kualitatif dengan melalui cara berpikir induktif.

\section{HASIL DAN PEMBAHASAN}

Pengertian Lingkungan Hidup

Seiring majunya zaman khususnya dalam bidang ekologi dan theologi, hampir seluruh lapisan masyarakat sudah mengetahui makna lingkungan hidup, maka penulis akan sedikit mengulas kembali makna lingkungan hidup secara bahasa maupun Istilah agar tidak memberikan makna yang luas. Lingkungan hidup dalam bahasa inggris disebut dengan Environment, kemudian dalam bahasa Belanda disebut dengan millieu, atau dalam bahasa Prancis disebut dengan I'environment (Siahaan, 2004a)

Istilah lingkungan hidup dapat diinterpretasikan sebagai salah satu unsur yang dapat memberikan manfaat dan dapat dipengaruhi oleh masing-masing individu, sehingga bilamana sebuah lingkungan hidup mampu dikelola dengan layak maka akan memberikan manfaat, sehingga perlu sebuah upaya mendasar pada diri manusia agar senantiasa faham akan apa yang Allah ciptakan. Maka bisa dikatakan bahwa 
lingkungan hidup merupakan keseluruhan unsur atau komponen yang berada di sekitar individu yang mempengaruhi kehidupan dan perkembangan individu yang bersangkutan (Sabartiyah, 2008). Istilah lingkungan hidup juga di utarakan oleh (Siahaan, 2004b) Ia menjelaskan bahwa lingkungan adalah semua benda, kekuatan, dan kondisi yang ada di tempat atau ruang tempat manusia atau organisme berada dan dapat dipengaruhi oleh kehidupannya. Kemudian (Sayyid Muhammad Al Husaini As Syairazi, n.d.) menjelaskan bahwa Lingkungan hidup secara umum didefinisikan sebagai segala sesuatu yang berada diluar diri manusia yang berhubungan dengan kehidupan manusia.

Dari beberapa penjelasan ahli di atas dapat disimpulkan bahwasannya lingkungan hidup merupakan seluruh benda, unsur maupun komponen yang berada di sekitar individu baik manusia maupun makhluk hidup yang mampu memberikan pengaruh antara satu dengan yang lainnya. Adanya lingkungan ini mampu menyediakan segala hal yang dibutuhkan manusia dari hal terkecil maupun yang sifatnya primer seperti air, udara maupun unsur-unsur yang lain.

Relevansi Penciptaan Manusia Dan Lingkungan: Perspektif Al-Qur'an

Adanya alam semesta yang Allah SWT, ciptakan merupakan sebuah kebesaran yang tiada tanding sebagai Al-Kholiq 'ala l'alami. Maka bisa dikatakan segala sesuatu selain Allah itulah alam secara sederhana
(Rostitawati, 2018). Pengertian ini merupakan pengertian teologis, dalam arti berdasarkan yang dikemukakan oleh para teolog Islam. .

Maka sebuah kewajiban bagi umat manusia untuk senantiasa bersyukur dan menjaga apa yang sudah dianugrahkan kepada manusia. Maka antara manusia dan alam semesta merupakan sebuah relasi yang tidak dapat dipisahkan antara satu dengan yang lain. Maka dari dua relasi tersebut akan memunculkan sebuah konsep yang dapat menjawab relasi antara manusia dengan lingkungan dengan menjadikan Al-Qur'an sebagai landasan utama, dua konsep tersebut yaitu:

Tujuan Penciptaan Alam Semesta

Menurut Al-Qur'an, alam bukan hanya benda yang tidak berarti apa-apa selain dimanfaatkan untuk memenuhi kebutuhan manusia. Alam dalam pandangan Islam adalah tanda (ayat) "keberadaan" Allah. Alam memberikan jalan bagi manusia untuk mengetahui keberadaan-Nya (Ramly, 2007). Artinya bahwa tujuan diciptakannya alam semesta diantaranya adalah sebagai alat agar makhluk yang diciptakannya dapat senantiasa mengingat, bersyukur dan memelihara kepada sang Pencipta bahwa yang menciptakan Alam dan seisinya adalah Allah SWT.

Menurut (Sakho, 2004) Tujuan diciptakannya alam semesta adalah sebagai berikut. Pertama, sebagai tanda atas kekuasaan Allah bagi yang berakal, mengetahui, 
bertaqwa, yang mau mendengarkan pelajaran dan yang berpikir. Kedua. supaya mampu memenuhi kebutuhan hidup manusia. Ketiga, sebagai rahmat dari Allah SWT. Keempat, sebagai kepentingan manusia. Kelima, untuk menguji siapa yang amalannya lebih baik. Dan Keenam, untuk menyempurnakan nikmat dan ujian bagi semua manusia.

Kemudian (Hamid, 1997) menuliskan dalam bukunya tentang beberapa fungsi alam dan lingkungan yang diciptakan oleh Allah, yaitu untuk semata-mata agar manusia beribadah dan mengingat kepada Allah.

\section{Tujuan Penciptaan Manusia}

Penciptaan manusia ke alam dunia merupakan sebuah anugrah yang luar biasa sehingga menjadikan kedudukan manusia sebagai makhluk yang paling sempurna, sehingga mampu mengemban tugas sebagai khalifah yang sudah dinisbatkan kepada manusia. Tentunya tujuan akhirnya yaitu menciptakan manusia untuk beribadah kepada Allah, manusia diciptakan untuk diperankan sebagai wakil tuhan di muka bumi dan untuk saling mengenal antara satu dengan yang lain, menghormati, dan untuk saling menolong antar sesama (Fathorrahman, 2019).

Al-Qur'an juga menggambarkan bagaimana manusia sebagai makhluk pilihan tuhan yaitu ditunjuk sebagai kholifah di muka bumi, yang mana tujuannya yaitu agar ada rasa tanggung jawab di dalam manusia itu sendiri. Sebagai makhluk yang memiliki bentuk dan rupa yang sempurna dibandingkan dengan makhluk lain, manusia dituntut untuk selalu berfikir tentang asal kejadiannya. Manusia yang berfikir adalah mereka yang selalu mengingat kepada kekuasaan Allah dan iradah-Nya. Dan manusia yang tidak berfikir yang selalu sibuk dengan kehidupan dunia, adalah mereka yang lupa asal kejadiannya, sehingga sifat-sifat sombong dan yang lainnya menjadi-jadi, baik di hadapan Allah maupun di hadapan makhluk Allah (Hakim Muda Harahap, 2013). Artinya bahwa tujuan penciptaan manusia di muka bumi ini adalah untuk senantiasa tunduk terhadap aturan Allah SWT. Dan memaksimalkan fitrah manusia sebagai suatu anugrah agar senantiasa menjaga marwah dan kedudukannya sebagai kholifah dimuka bumi agar tidak berbuat kerusakan.

Rahardjo menyimpulkan (Rahardjo, 1996) bahwa terdapat tiga makna khalifah. Pertama, khalīfah dalam al-Qur'an berarti Adam as. Sebagai simbol manusia pertama, ini berarti manusia adalah penguasa di muka bumi. Kedua, khaliffah berarti generasi penerus atau pengganti, sehingga fungsi khalīfah diamanatkan secara kolektif kepada suatu generasi. Dan terakhir, khalīfah berarti kepala negara atau raja suatu kaum. Hubungan antara manusia dengan alam dalam al-Qur'an di mana manusia berkedudukan sebagai khalifah, harus juga dilihat dari segi penundukan (taskhir) dan kehambaan (al-'ubüdiyyah). Manusia selaku khalifah di bumi dilengkapi dengan 
kemampuan mengembangkan pengetahuan dan ditundukkannya alam semesta dan seisinya untuk manusia. Allah lah yang menundukkan langit dan bumi dan seisinya bukan manusia. Oleh karena itu, meskipun manusia sebagai khalifah diberi kuasa untuk mengelola dan memelihara alam, kedudukan manusia dengan alam semesta adalah setara di hadapan Allah (Nasr, 1990).

Dari berbagai pandangan di atas maka hubungan antara manusia dengan lingkungan merupakan sebuah hubungan teorisitis antara ekologis dan spiritualis yang tidak dapat terpisahkan, dimana Allah SWT. Sebagai zat seluruh alam menjadikan alam semesta sebagai alat untuk meningkatkan hal spiritualis agar manusia senantiasa bersyukur kepadanya, sedangkan manusia dikaruniai sebuah akal agar senantiasa saling menjaga dan mengasihi, anatara manusia dengan manusia yang lain, serta antara manusia dengan alam.

Maka jika dilihat dalam kerangka pandangan agama dan lingkungan di atas, maka konsep ini akan lebih sesuai dengan dengan konsep hubungan antara manusia dengan seluruh makhluk Allah.

\section{Tanggung Jawab dan Larangan manusia terhadap} lingkungan dan Alam Semesta

Prinsip hormat manusia terhadap lingkungan adalah tanggung jawab moral terhadap alam, karena manusia diciptakan sebagai khalifah di muka bumi dan secara ontologis manusia adalah bagian integral dari alam. Dalam pandangan agama, manusia dituntut untuk mampu menghormati prosesproses yang sedang tumbuh, dan terhadap apa saja yang ada. Sebagaimana yang disampaikan oleh (Masitoh, 2015) bahwa etika agama terhadap alam (lingkungan) mengantarkan manusia untuk bertanggung, jawab sehingga ia tidak melakukan perusakan atau dengan kata lain "setiap perusakan terhadap lingkungan harus dinilai sebagai perusakan pada diri manusia sendiri”. Kenyataan ini melahirkan sebuah prinsip moral bahwa manusia mempunyai tanggung jawab baik terhadap alam semesta dan integritasnya, maupun terhadap keberadaan dan kelestariannya.

Meskipun semua makhluk ciptaan Allah memiliki status yang sama di hadapan Allah, namun manusia diberikan tanggung jawab yang berbeda daripada makhluk ynag lain. Manusia diberikan kelebihan dengan "kesempurnaan" akal dan fikiran. Oleh karena itu pola perkembangan manusia sangatlah berbeda dengan perkembangan makhluk hidup lainnya. Dengan berbagai kelebihan seperti halnya otak, manusia dapat mengembangkan ilmu pengetahuan dan teknologi, akan tetapi lebih dari itu semua juga untuk mengembangakan dan meningkatkan kebaikan umat.

Dalam Islam, besarnya tanggung jawab yang diberikan kepada manusia karena manusia menduduki puncak ciptaan Allah yang tertinggil dan sempurna. Sebagaimana dalam Q.S. Al-Isra: 70 sebagai berikut. 
Artinya: Dan sesunggubnya telah Kami muliakan anak-anak. Adam, Kami angkut mereka di daratan dan di lautan, Kami beri mereka rezeki dari yang baik-baik dan Kami lebibkan mereka dengan kelebihan yang sempurna atas kebanyakan makbluk yang telah Kami ciptakan.

Adapun ayat lain yang menjelaskan tentang tanggung jawab manusia terhadap lingkungam yaitu terdapat pada Q.S. AlAn'am : 165 sebagai berikut :

Artinya: Dan dialah yang menjadikan kalian penguasa-penguasa di bumi dan Dia meninggikan sebagian kalian atas sebagian (yang lain) beberapa derajat, untuk menguji kalian tentang apa yang diberikan-Nya kepada kalian. Sesungoubnya Tuhanmu amat cepat siksaan-Nya, dan sesunggubnya Dia Maha Pengampun lagi Maha Penyayang.

Apa yang ditegaskan Allah demikian yaitu agar manusia selalu mengingat dan selalu bersyukur. Karena hakikatnya manusia diciptakan oleh Allah sebagai penguasapenguasa di muka bumi, maka sudah sepantasnya untuk menjaga apa yang Allah berikan kepada kita.

Walaupun manusia diciptakan dengan berbagai kelebihan yang ada, namun tidak menutup kemungkinan bahwa tidaklah mampu untuk hdup sendiri tanpa ciptaan Allah yang lain. Manusia sebagai makhluk sosial, tentunya memiliki peran penting dalam menjaga keseimbangan alam/lingkungan, maka perlu di tegaskan bahwa merusak maupun eksploitasi merupakan sebuah larangan. Maka Islam selalu memandang bahwa kekholifahan yang diemban oleh manusia agar selalu diimplementasikan dalam menjaga alam semsesta, sebagaimana yang dijelaskan oleh (Shihab, 2007) bahwa Agama mengundang kita untuk membangun tanpa merusak, setelah mengemukakan dan menyadari pandangan agama tentang makna kekhalifahan yang menjadi tujuan kehadiran manusia dibumi ini, maka tidak heran bila puluhan kalau enggan berkata puluhan ayat al-Quran dan hadis Nabi saw yang dijadikan landasan berpijak guna tercapainya kelestarian dan pemanfaatan lingkungan.

Perilaku menyimpang yang dilakukan oleh manusia juga dijelaskan dalam Q.S. AlBaqarah/2:11 sebagai berikut:

Artinya :"Dan bila dikatakan kepada mereka: Janganlah kamu berbuat kerusakan di muka bumi, mereka menjawab: Sesunggubnya Kami orang-orang yang Mengadakan perbaikan

Maksud perusak dalam ayat tersebut adalah Kaum perusak, yang mengaku sebagai muslibin, suatu gejala yang ada disetiap masa. Larangan pada ayat ini ditunjukan kepada hal-hal yang akan membuat kerusakan (Ahmad Mustafa Al-Maraghi, 1992).

Maka dari telaah literatur diatas dapat disimpulkan bahwa Al-Qur'an telah mengatur dan melarang atas apa yang sudah Allah berikan kepada manusia melalui ayat ayat yang ada didalamnya, sehingga apabila itu terjadi maka Allah akan peringatkan dengan berbagai peringatan agar manusia selalu mengingat dan bersyukur atas apa yang sudah diciptakan oleh Allah SWT. 


\section{KESIMPULAN}

Sebenarnya, dalam kajian tentang konsep manusia dan lingkungan melalui perspektif Al-Qur'an ini pada intinya adalah mengkaji sebuah relevansi antara manusia dengan alam semesta, atas apa yang sudah di patenkan dalam Al-Qur'an melalui ayat ayat pilihan agar manusia semakin memahami atas kebesaran Allah yang berupa alam semesta. Maka dalam konteks ini posisi Manusia sebagai khalifatullob fil Ard memiliki kedudukan penting agar mampu menggunakan segala kelebihan yang Allah SWT, berikan sebagai alat untuk mendekatkan diri kepada Allah, sebagaimana tujuan manusia diciptakan dibumi ini, yang tidak lain untuk semata mata menyembah kepada Allah.

Maka dari itu berdasarkan hasil kajian Tafsir Al-Qur'an, selain manusia dengan lingkungan terdapat beberapa relasi yang saling mempengaruhi antara satu dengan yang lain yaitu antara tuhan dengan manusia dan alam semesta dengan tuhan, sehingga seluruh relasi tersebut akan akan memberikan keseimbangan antara, alam dan manusia.

\section{DAFTAR PUSTAKA}

Abdillah, M. (2001). Agama ramah lingkungan: perspektif al-Quran (Vol. 6). Paramadina.

Ahmad Mustafa Al-Maraghi. (1992). Terjemah Tafsir Al-Maraghi, Juz 1,. PT Karya Toha Putra.

Cahaya Qur'an. (2017). Al Qur'anul Karim
AL-AMZAR terjemah dan transliterasi

lati. PT. Dinamika Cahaya Pustaka.

Fathorrahman, F. (2019). Konsep Fitrah Dalam Pendidikan Islam. Tafbim Al'Ilmi, 11(1), 34-46.

Hakim Muda Harahap. (2013). Rahasia AlQuran; Menguak Alam, Manusia, Malaikat, Dan Keruntuban Alam. Darul Hikmah.

Hamid, A. (1997). Exploring the Islamic Environmental Ethics. Islam and the Environment. Genuine Publications: Kuala Lumpur.

Kaveh L. Afrasiabi. (2003). "Toward an Islamic Ecotheology," dalam Islam and Ecology: A Bestowed Trust. The President and Fellows of Harvard College.

La Fua, J. (2014). Aktualisasi Pendidikan Islam dalam Pengelolaan Lingkungan Hidup Menuju Kesalehan Ekologis. Al-TA'DIB: Jurnal Kajian Ilmu Kependidikan, 7(1), 19-36.

Mangunjaya, F. M. (2013). Islam and Natural Resource Management. Integrating Religion Within Conservation: Islamic Beliefs and Sumatran Forest Management, 11.

Masitoh, S. (2015). Konsep Etika Lingkungan Perspekif al-Qur'an: Studi Tafsir Tematik. Jurnal Al-Fath, 9(02).

Nasr, S. H. (1990). Islam and the environmental crisis. Islamic Quarterly, 34(4), 217.

Rahardjo, M. D. (1996). Ensiklopedi al-Qur'an: tafsir sosial berdasarkan konsep-konsep 
DOI: $10.29313 /$ tjpi.v10i1.7481

kunci. Diterbitkan oleh Penerbit

Paramadina bekerjasama Jurnal

Ulumul Qur'an.

Ramly, N. (2007). Islam ramah lingkungan: konsep dan strategi Islam dalam pengelolaan, pemeliharaan, dan penyelamatan lingkungan hidup. Grafindo Khazanah Ilmu.

Rostitawati, T. (2018). Tuhan, Manusia Dan Alam Dalam Perspektif Filsafat Pendidikan Islam. Irfani, 14(1), 28-42. Sabartiyah. (2008). Pelestarian Lingkungan
Hidup.

Sakho, M. A. (2004). Fiqih Lingkungan (Figh alBi'ab).

Sayyid Muhammad Al Husaini As Syairazi. (n.d.). Figh Bi'ah. Muassasah al Wa'yu al-Islamy),

Shihab, M. Q. (2007). “Membumikan” AlQuran: fungsi dan peran wabyu dalam kehidupan masyarakat. Mizan Pustaka.

Siahaan, N. H. T. (2004). Hukum lingkungan dan ekologi pembangunan. Erlangga. 
Human Concept of The Environment and The Universe Perspective of The Quran DOI: 10.29313/tjpi.v10i1.7481

34 | Ta'dib: Jurnal Pendidikan Islam, 10(1), 2021 